\title{
Peruvian pharmacist employment and wage: Gender, university and type of job influences
}

\author{
Luz CHACAlTANA $^{1}$ (D), Josefa PARI 1 (D), Pompeyo CUBA 2 (D), Luzmila HERNANDEZ ${ }^{3}$ (D), \\ Juana LA ROSA 4 (D), Cecilia SOLANO 5 (D), Melisa QUISPE 6 (D), Alfredo OYOLA ${ }^{6 *}$ (D)
}

1 Department of Pharmacochemistry, Faculty of Pharmacy and Biochemistry, San Luis Gonzaga University, Ica, Perú.

2 Department of Chemical Sciences, Faculty of Pharmacy and Biochemistry, San Luis Gonzaga University, Ica, Perú.

3 Department of Community Sciences, Faculty of Dentistry, San Luis Gonzaga University, Ica, Perú.

4 Department of Medicine and Oral Surgery, Faculty of Dentistry, San Luis Gonzaga University, Ica, Perú.

5 Department of Basic Sciences, Faculty of Dentistry, San Luis Gonzaga University, Ica, Perú.

6 Department of Public Health Research, Natural and Social Sciences Research, Lima, Perú.

* Corresponding Author. E-mail: aoyolag@gmail.com (A.O.); Tel. +51-1-956 124996.

Received: 03 August 2018 / Revised: 02 October 2018 / Accepted: 04 October 2018

ABSTRACT: Wage is a key element for the performance of the health professional. Because of that, an observational study was carried out based on the secondary analysis of the main results from the "National Survey of University Graduates and Universities (NSUGU), 2014" to identify the conditioning factors of inequality in accessing to the labor market and low wage of Peruvian pharmacists. Chi square, crude Odds Ratio (cOR) and adjusted Odds Ratio (aOR) with $95 \%$ confidence interval were calculated. In the bivariate analysis the work not related to pharmaceutical training exposed pharmacists to almost four and a half times the risk of a remuneration lower than 1000 PEN compared to those who had a job related to their professional training $(\mathrm{cOR}=4.473)$ and it increased to six times in the multivariate analysis $(\mathrm{cOR}=5.938)$. Women were less likely to have this remuneration than men $(\mathrm{cOR}=0.544)$ and maintained this characteristic in the multivariate analysis. The graduation from a public university was a protective factor of remuneration lower than $1000 \mathrm{PEN}$ in the multivariate analysis, but not in the bivariate analysis. Women and graduates from public universities are more likely to be unemployed, while exposure to low income is measured by occupation not related to professional training.

KEYWORDS: Pharmacyst; wage; employment; inequality.

\section{INTRODUCTION}

Wage is a key element for the performance of the health professional because it can determine job dissatisfaction [1,2], alteration of the organizational environment [3] and affect the quality of life at work [4] by acting as a stressor [5]. If they are not satisfied during their performance and with the results obtained they could not develop their work with quality and efficiency [6], and could not contribute to the guarantee of quality health care [7] and to the universal health coverage [8,9].

In the last decade, Peru has been one of the fastest growing economies in Latin America and the Caribbean. This has improved the growth of employment and incomes that have reduced economic inequality inside the country [10]. However, in the last national survey of university graduates by the National Institute of Statistics and Informatics (NISI) [11], there is a wage disparity that would reveal the professional wage disparity in the labor market [12] despite the fact that higher education level should increase the probability of participation and better wage in the labor market [13].

Several international [14-20] and Peruvian studies [21,22], most of them developed in physicians, showed evidence that the existing labor discrimination in the health system is mainly mediated by gender. A study conducted by Carvajal et al. [23] also showed this disparity in pharmacists in the United States; men had better income than their female counterparts. In Peru, another study [24] found that the type of contract conditioned salary disparity, but studies that show other factors involved in these pharmacist wage differences have not been found.

How to cite this article: Chacaltana L, Parı J, Cuba P, Hernandez L, La Rosa J, Solano C, Quispe M, Oyola A. Peruvian pharmacist employment and wage: gender, university and type of job influences. J Res Pharm. 2019; 23 (2): 284-291. 
Considering that differences in the total income of health professionals, the causes behind them, and the inequalities they generate are part of the research agenda of health human resources [25], further study of wage disparities in pharmacists is warranted for contributing to the design of policies and decision. Therefore, the aim of the current study is to identify the conditioning factors of inequality in accessing to the labor market and low wage in Peruvian pharmacists.

\section{RESULTS}

In Table 1, after bivariate analysis, unemployment was twice more likely in women (cOR=2.012), more than twice in pharmacists graduated in a public university $(\mathrm{cOR}=2.334)$ and nearly three times when the university was located outside of Lima or Callao ( $(\mathrm{OR}=2.704)$. However, multivariate analysis determined that the pharmacists graduated from a public university had the highest risk of unemployment $(\mathrm{COR}=2.508)$ followed by female ones ( $\mathrm{cOR}=2.447)$ and, finally, the location of the university (outside of Lima and Callao).

Table 1. Activity condition by gender, type of university management, and location of the university.

\begin{tabular}{|c|c|c|c|c|c|c|c|c|}
\hline \multirow{2}{*}{ Characteristic } & \multicolumn{2}{|c|}{ Unemployed } & \multicolumn{2}{|c|}{ Employed } & \multirow{2}{*}{$\begin{array}{c}\text { Total } \\
\mathbf{n}\end{array}$} & \multirow{2}{*}{$\underset{\text { value }}{p}$} & \multicolumn{2}{|c|}{ Odds Ratio (IC 95\%) } \\
\hline & $\mathrm{n}$ & $\%$ & $\mathrm{n}$ & $\%$ & & & Crude & Adjusted* \\
\hline \multicolumn{9}{|l|}{ Gender } \\
\hline Female & 96 & 9.34 & 929 & 90.66 & 1025 & \multirow{2}{*}{0.009} & $2.012(1.183-3.421)$ & \multirow[t]{2}{*}{$2.447(1.412-4.243)$} \\
\hline Male & 17 & 4.96 & 331 & 95.04 & 348 & & 1 & \\
\hline \multicolumn{9}{|c|}{ Type of university management } \\
\hline Public & 74 & 11.56 & 565 & 88.44 & 639 & \multirow{2}{*}{0.006} & $2.334(1.559-3.494)$ & \multirow[t]{2}{*}{$2.508(1.637-3.844)$} \\
\hline Private & 39 & 5.33 & 695 & 94.67 & 734 & & 1 & \\
\hline \multicolumn{9}{|c|}{ Location of the university } \\
\hline $\begin{array}{l}\text { Other places in } \\
\text { the country }\end{array}$ & 96 & 10.09 & 852 & 89.91 & 948 & \multirow[b]{2}{*}{0.020} & $2.704(1.593-4.590)$ & \multirow[t]{2}{*}{$1.919(1.111-3.312)$} \\
\hline $\begin{array}{l}\text { Lima and } \\
\text { Callao }\end{array}$ & 17 & 4.07 & 408 & 95.93 & 425 & & 1 & \\
\hline
\end{tabular}

*Hosmer - Lemeshow $=1.27 ; \mathrm{p}=0.5197$

In bivariate analysis it was also observed that work not related to pharmaceutical training exposed pharmacists to almost four and a half times the risk of less than 1000 PEN remuneration compared to those with a job related to their professional training $(\mathrm{cOR}=4.473)$ and it increased to six times in the multivariate analysis $(\mathrm{cOR}=5.938)$. Conversely, women were less likely to have this low remuneration than men $(\mathrm{COR}=$ 0.544 ) and maintained this characteristic in multivariate analysis. Likewise, the graduation from a public university also behaved as a protective factor of remuneration lower than 1000 PEN in the multivariate analysis, but not in the bivariate analysis (Table 2).

Finally, in Table 3, through bivariate and multivariate analysis it was observed there was a greater probability -between three and eight times- of having two occupations in pharmacists graduated from public universities or from universities located outside of Lima and Callao, and in whose main jobs were not related to professional training ( $\mathrm{cOR}=3,281, \mathrm{cOR}=8,092$, and $\mathrm{cOR}=4,770$, respectively). Likewise, the female gender and income $<1000$ PEN in the main job were factors that reduced the probability of working in two occupations.

\section{DISCUSSION}

Three out of four pharmacists were women in our study population [26], but traditional social patterns would limit their participation in the Peruvian labor market [27]. This situation has caused a lower employment rate of the economically active female population [28] despite being university graduates. Findings if this research show that women pharmacists would have a higher probability of being unemployed besides being limited to only one type work. 
Table 2. Total wage by gender, type of university management, location of the university, and type of main job.

\begin{tabular}{|c|c|c|c|c|c|c|c|c|}
\hline \multirow{2}{*}{ Characteristic } & \multicolumn{2}{|c|}{$<1000$ PEN } & \multicolumn{2}{|c|}{$\geq 1000$ PEN } & \multirow{2}{*}{$\begin{array}{c}\text { Total } \\
\mathbf{n} \\
\end{array}$} & \multirow{2}{*}{$\underset{\text { value }}{p}$} & \multicolumn{2}{|c|}{ Odds Ratio (IC 95\%) } \\
\hline & $\mathbf{n}$ & $\%$ & $\mathbf{N}$ & $\%$ & & & Crude & Adjusted* \\
\hline \multicolumn{9}{|l|}{ Gender } \\
\hline Female & 233 & 25.1 & 697 & 74.9 & 930 & \multirow{2}{*}{0.000} & $0.544(0.416-0.710)$ & \multirow[t]{2}{*}{$0.392(0.289-0.533)$} \\
\hline Male & 126 & 38.1 & 205 & 61.9 & 331 & & 1 & \\
\hline \multicolumn{9}{|c|}{ Type of university management } \\
\hline Public & 155 & 27.4 & 410 & 72.6 & 565 & \multirow{2}{*}{0.453} & $0.910(0.711-1.164)$ & \multirow[t]{2}{*}{$0.668(0.501-0.889)$} \\
\hline Private & 204 & 29.4 & 491 & 70.6 & 695 & & 1 & \\
\hline \multicolumn{9}{|c|}{ Location of the university } \\
\hline $\begin{array}{l}\text { Other places in the } \\
\text { country }\end{array}$ & 236 & 27.7 & 616 & 72.3 & 852 & \multirow[t]{2}{*}{0.417} & $0.898(0.693-1.164)$ & \multirow[t]{2}{*}{$0.988(0.752-1.299)$} \\
\hline Lima and Callao & 122 & 29.9 & 286 & 70.1 & 408 & & 1 & \\
\hline \multicolumn{9}{|l|}{ Type of main job } \\
\hline Non-related & 39 & 61.9 & 24 & 38.1 & 63 & \multirow{2}{*}{0.000} & $4.473(2.647-7.556)$ & \multirow[t]{2}{*}{$5.938(3.466-10.173)$} \\
\hline Related & 319 & 26.6 & 878 & 73.4 & 1197 & & 1 & \\
\hline
\end{tabular}

*Hosmer and Lemeshow: 0.635; $\mathrm{p}=0.888$

Table 3. Number of jobs by gender, type of university management, location of the university, type of main job, and main job wage.

\begin{tabular}{|c|c|c|c|c|c|c|c|c|}
\hline \multirow{2}{*}{ Characteristic } & \multicolumn{2}{|c|}{$\begin{array}{c}\text { Two jobs or } \\
\text { more }\end{array}$} & \multicolumn{2}{|c|}{ Only one job } & \multirow{2}{*}{$\frac{\text { Total }}{n}$} & \multirow[t]{2}{*}{$\mathbf{P}$} & \multicolumn{2}{|c|}{ Odds Ratio (IC 95\%) } \\
\hline & n & $\%$ & $\mathbf{N}$ & $\%$ & & & Crude & Adjusted* \\
\hline \multicolumn{9}{|l|}{ Gender } \\
\hline Female & 143 & 15.4 & 786 & 84.6 & 929 & \multirow{2}{*}{0.000} & $0.414(0.309-0.556)$ & \multirow[t]{2}{*}{$0.402(0.281-0.577)$} \\
\hline Male & 101 & 30.5 & 230 & 69.5 & 331 & & 1 & \\
\hline \multicolumn{9}{|c|}{ Type of university management } \\
\hline Public & 182 & 32.2 & 383 & 67.8 & 565 & \multirow{2}{*}{0.000} & $4.852(3.541-6.647)$ & \multirow[t]{2}{*}{$3.281(2.319-4.642)$} \\
\hline Private & 62 & 8.9 & 633 & 91.1 & 695 & & 1 & \\
\hline \multicolumn{9}{|c|}{ Location of the university } \\
\hline $\begin{array}{l}\text { Other places in the } \\
\text { country }\end{array}$ & 227 & 26.6 & 626 & 73.4 & 853 & \multirow{2}{*}{0.000} & $\begin{array}{c}8.340(5.014- \\
13.872)\end{array}$ & \multirow[t]{2}{*}{$\begin{array}{c}8.092(4.790- \\
13.672)\end{array}$} \\
\hline Lima and Callao & 17 & 4.2 & 391 & 95.8 & 408 & & 1 & \\
\hline \multicolumn{9}{|l|}{ Type of main job } \\
\hline Non-related & 24 & 38.1 & 39 & 61.9 & 63 & \multirow{2}{*}{0.000} & $2.733(1.610-4.639)$ & \multirow[t]{2}{*}{$4.770(2.484-9.159)$} \\
\hline Related & 220 & 18.4 & 977 & 81.6 & 1197 & & 1 & \\
\hline \multicolumn{9}{|l|}{ Main job wage } \\
\hline$<1000$ PEN & 57 & 17.0 & 279 & 83.0 & 336 & \multirow{2}{*}{0.193} & $0.805(0.581-1.117)$ & \multirow[t]{2}{*}{$0.644(0.442-0.936)$} \\
\hline$\geq 1000 \mathrm{PEN}$ & 187 & 20.2 & 737 & 79.8 & 924 & & 1 & \\
\hline
\end{tabular}

*Hosmer and Lemeshow: 8.106; $\mathrm{p}=0.151$

This may be due to the lower willingness for accepting positions with long working hours, the reduced willingness to travel and relocate [29] due to domestic activities carried out at home [30,31], and the pressure from their families to prioritize this domestic role instead of paid workers role [32]. Women cannot be substituted when they are absent from the house [33], so more women than men would be looking for part time work during their childrearing years [34]. However, some differences in wages were attributed to employers' characteristics, including gender discrimination [23,34].

Although the economic income of women is $30 \%$ lower compared to the male gender [28] and moreso if the employee is a mother [35] our results showed that when women are inside of the labor market they would not be exposed to low wages. However, some studies have shown that women have lower earnings than men [36,37] because they prefer other non-pecuniary advantages that act as compensating differentials [38-40].

Low professional quality [41] due to the lack of periodic evaluations of the pharmacy faculties curricula, and the oversupply mainly in the private labor market [26] as a consequence of the greater number of private universities and higher enrollment [42] could be the factors involved in the greater risk of unemployment 
experienced by professionals graduated from public universities. Also, the incorporation of technologies in the pharmaceutical market has been associated to this problem, because it systematizes and industrializes the work of the pharmacist and impacts on the demand of qualified professionals [4]. Likewise, they would be conditioned to have two jobs when the main activity is not related to their professional training or if they reside in the inner country, in order to obtain adequate remuneration as evidenced by this result. This finding is important because the type of university can also be related to the family socioeconomic level of pharmacists $[43,44]$; the cost of education in private universities could be five times the cost in a public university [45-47]. So access to them would be restricted for low income people [46]. Results of this research also reflect the influence of centralism when accessing employment, because the universities that enable greater labor insertion are in Lima, the capital of Peru [47]. So it becomes a decisive factor to apply for two or more occupations that allow sufficient income to meet their needs. Carvajal et al. [36] found that wages and salaries were more unequally distributed within large city practitioners than within pharmacists practicing outside large cities, especially full-time pharmacists. Other studies have shown that race, ethnicity, rural residence and/or practice exerts a negative effect on pharmacists' earnings [27,48].

When interpreting these results, several limitations inherent to the study must be taken into account. Because it is a secondary analysis, it has not been possible to analyze other factors involved in unemployment and labor remuneration such as: marital status, area of residence, work dependence, family composition, race, ethnicity [13,48], age, physical appearance [36,49] or the presence of disability [50]. Also, the unemployment variable should not be considered as an indicator of job opportunities deficit [51] because the unemployed may be looking for a job with better income [13]. Likewise, having two jobs does not imply that this decision is voluntary, possibly mediated by the lack of access to a full-time job and, therefore, a decent remuneration $[32,48]$.

\section{CONCLUSION}

In conclusion, differences in the income of pharmacysts are present in the Peruvian labor market. This is influenced by gender, university, and type of job. Women and graduates from public universities are more likely to be unemployed, while exposure to low income is measured by occupation not related to professional training. These factors, plus the characteristics of the university, would force pharmacists to work in two jobs, but limited for women. In that sense, university education is not acting as a mechanism to achieve equal employment opportunities in the country. Therefore, it is necessary to deepen the analysis of these variables to eliminate these barriers that create differences in the labor market.

\section{MATERIALS AND METHODS}

\subsection{Study design}

An observational study was carried out based on the secondary analysis of the main results from the "National Survey of University Graduates and Universities (NSUGU), 2014" [11].

\subsection{Study population}

The study population was made up of pharmacists who had at least one year of university graduation at the time of the survey with less than 3 years of study delay in the course of their career, and who did not have more than 25, 26 and 27 years in their last year of studies according to the extension of their career $(5,6$ and 7 years, respectively). The sampling frame was obtained from the National University Census (NUC) conducted in 2010 by NISI. The sample was probabilistic, stratified one-stage list (one-stage) and independent in each university career and selected university and included 82 pharmacists.

\subsection{Variables}

The activity condition, total wage, and number of jobs were considered as dependent variables. Based on the questionnaire used in the NSUGU activity condition was measured based on question 401 of the questionnaire -"Did you have any job last week?"-, those who answered "yes" were the employed pharmacists and those who answered "no" were the unemployed ones. Total wage was measured from the sum of the income reported by the graduates in questions 436 to 438 and grouped into two categories: less than 1000 PEN and equal to or greater than 1000 PEN. Number of jobs was obtained from question 418 of the questionnaire "What is the secondary occupation that was performed?" those who answered the secondary occupation were considered with two occupations and those who did not answer were considered a single occupation. 
The independent variables were: gender, type of university management, and location of the university. Type of main job was considered an independent variable for total wage and number of jobs, and total wage was considered an independent variable for number of jobs. Gender was measured from question 11 -"gender of the graduate"- and had two answers male and female. Type of university management was measured from question 311 of the questionnaire -"What is the name of the last university from which he graduated?"-, with two responses: public and private; finally,. Location of the university was determined from module 09 "identification and location of the university, department, province and district"- and categorized as Lima and Callao (the name Lima corresponds to the province of Lima, capital of Peru) and the rest of the country. Type of main occupation -relation between job and the professional training- was measured from question 406 of the questionnaire -"Is the job you did related to your professional training?"- with two possible answers, "related" and "non-related". Remuneration of the main job was measured from the sum of the income reported by the graduates in questions 436 and 437 , and grouped into two categories: less than 1000 PEN $(\approx 347.83$ US dollars) and equal to or greater than 1000 PEN.

\subsection{Processing of data}

The database was downloaded from the web portal of the National Institute of Statistics and Informatics (NISI - www.inei.gob.pe). The databases of all the surveys carried out by the NISI can be found in the "Micro data" section of the "Databases" menu. From this menu you can access the tab "Query by Survey" and select the "National Survey of University Graduates and Universities", then select the year ("2014"). "Annual" was chosen in the period.

The survey of graduates is composed of eleven modules: $587,588,589,590,591,592,593,594,595,596$ and 600. In order to form the database, a fusion of databases was carried out (merge) of modules 587, 590 and 592 with the help of statistical software IBM SPSS ${ }^{2} 23$ and Stata ${ }^{\circledR} 14$.

Expansion factors were used for the presentation of the results because of data was obtained from a sample. According to sampling theory, the expansion factor is the ability of each individual selected in a probabilistic sample to represent the population. In stratified sampling, the expansion factors or sample weights are obtained as the quotient between the size of the stratum and the size of the sample in said stratum [52].

\subsection{Analysis of data}

The chi square and the $p$ value in $2 \times 2$ squares were calculated for the variables gender, type of university management, location of the university, type of main job, and main job wage.

The aOR and its 95\% CI was calculated in the bivariate analysis, assuming the categories "male" for gender, "private" for type of university management, "Lima and Callao " for location of the university, "related" for type of job and "equal to or more than 1000 PEN" in the main job wage as negative factor.

The logistic regression model was used in the multivariate analysis to identify and describe the association of each of the dependent variables with independent ones, through the aOR and its $95 \% \mathrm{CI}$. The Hosmer and Lemeshow test was used to evaluate the logistic regression model goodness-of-fit, and to check whether the proposed model - in our case the logistic model- can explain what it observes by assuming as a null hypothesis: "there are no differences between the observed values and the predicted values". His rejection - by using the chi-square- indicated that the model was not well adjusted [53].

\subsection{Ethics}

The published statistical data did not contain personal identification variables. No permission was required because the NISI offers users all the information contained on its website whenever the source is cited [54].

Acknowledgement: The author, Alfredo Oyola, would like to thank Fred Schneider M.D. for his support in the translation of this work.

Author contributions: Concept - L.CH., P.C., J.P., L.H., J.LR., C.S; Design - M.P., A.O.; Supervision - C.S.; Materials L.H., J.LR.; Data Collection and/or Processing - L.H., J.LR.; Analysis and/or Interpretation - M.P., A.O.; Literature Search - L.CH., P.C., J.P.; Writing - L.CH., P.C., J.P., M.P., A.O.; Critical Reviews -L.H., J.LR.,C.S., L.CH., P.C., J.P., M.P., A.O.

Conflict of interest statement: The authors declared no conflict of interest in the manuscript. 


\section{REFERENCES}

[1] Baldeón C. Factores asociados a la satisfacción del personal de salud del Hospital IV Ramiro Priale Priale, Huancayo. Ágora Rev Cient. 2015; 2(1):112-124. [CrossRef]

[2] Paredes ME, País D. Satisfacción laboral de las enfermeras del Hospital Provincial Docente Belén de Lambayeque. Rev. Salud \& Vida Sipanense. 2015; 2(1):17-25.

[3] Del Rio-Mendoza JRJ, Munares-Lovaton A, Montalvo-Valdez H. Clima organizacional en trabajadores de un hospital general de Ica. Rev Méd Panacea. 2013; 3(1):11-14.

[4] Flores R, Madero SM. Factores de la calidad de vida en el trabajo como predictoras de la intención de permanencia. Acta Universitaria. 2012; 22(2):24-31. [CrossRef]

[5] Cirera Y, Aparecida E, Rueda S, Ferraz O. Impacto de los estresores laborales en los profesionales y en las organizaciones. Invenio. 2012; 15(29): 67-80.

[6] Pavón-León P, Gogeascoechea-Trejo MC, Blázquez-Morales MSL, Blázquez-Domínguez CR. Satisfacción del personal de salud en un hospital universitario. Salud en Tabasco. 2011; 17(1-2):13-21.

[7] Soto A. Recursos humanos en salud. Rev Peru Med Exp Salud Publica. 2011; 28(2):173-174.

[8] Campbell J, Buchan J, Cometto G, David B, Dussault G, Fogstad H, Fronteira I, Lozano R, Nyonator F, Pablos-Méndez A, Quain EE, Starrs A, Tangcharoensathien V. Human resources for health and universal health coverage: fostering equity and effective coverage. Bull World Health Organ. 2013; 91: 853-863. [CrossRef]

[9] Sales M, Kieny M-P, Krech R, Etienne C. Human resources for universal health coverage: from evidence to policy and action. Bull World Health Organ. 2013; 91:798-798A. [CrossRef]

[10] Perú: Panorama general. http://www.bancomundial.org/es/country/peru/overview (accessed August 1, 2018).

[11] INEI. Perú: Encuesta nacional a egresados universitarios y universidades, 2014: Principales resultados. https://www.inei.gob.pe/media/MenuRecursivo/publicaciones_digitales/Est/Lib1298/Libro.pdf (accessed August 1, 2018).

[12] Informe Mundial sobre Salarios 2014/2015: La brecha salarial entre ambos sexos se amplía para las mujeres mejor remuneradas. http://www.ilo.org/global/about-the-ilo/newsroom/news/WCMS_324700/lang--es/index.htm (accessed August 1, 2018).

[13] Arpi R, Arpi L. Retornos heterogéneos a la educación en el mercado laboral peruano, 2015. Rev Investig Altoandin. 2016; 18(3):289-302.

[14] Coplan B, Essary AC, Virden TB, Cawley J, Stoehr JD. Salary discrepancies between practicing male and female physician assistants. Women's Health Issues. 2012; 22(1):e83-e89. [CrossRef]

[15] Jagsi R, Griffith KA, Stewart A, Sambuco D, DeCastro R, Ubel PA. Gender differences in salary in a recent cohort of early career physician-researchers. Acad Med. 2013; 88:1689-1699. [CrossRef]

[16] Brown LM, Schommer JC, Mott D, Gaither CA, Doucette WR, Zgarrick DP, Droege M. Examining gender salary disparities: an analysis of the 2003 multistate salary survey. Res Social Adm Pharm. 2006; 2:370-e387. [CrossRef]

[17] Coombs J, Valentin V. Salary differences of male and female physician assistant educators. J Physician Assist Educ. 2014; 25(3):9-14.

[18] Kapoor N, Blumenthal DM, Smith SE, Ip IK, Khorasani R. Sex differences in radiologist salary in U.S. public medical schools. AJR Am J Roentgenol. 2017; 209:953-958. [CrossRef]

[19] Wilson BL, Butler RJ, Butler MJ. Employment and wage disparities for nurses with activity limitations. J Nurs Scholarsh. 2016; 48(6):1-8. [CrossRef]

[20] Jena AB, Olenski AR, Blumenthal DM. Sex differences in physician salary in U.S. public medical schools. JAMA Intern Med. 2016; 176(9):1294-1304. [CrossRef]

[21] Taype-Rondan A, Torres-Roman JS, Herrera-Añazco P, Alva Diaz C, Brañez-Condorena A, Moscoso-Porras AG. Ingresos económicos en médicos peruanos según especialidad: un análisis transversal de la ENSUSALUD 2015. Rev Peru Med Exp Salud Publica. 2017; 34(2):183-191. [CrossRef]

[22] Taype-Rondan A, Alarcon-Ruiz CA, Zafra-Tanaka JH, Rojas-Vilar FJ. Factores asociados al ingreso económico, carga laboral y clima laboral en un grupo de médicos generales jóvenes en Perú. Acta Med Peru. 2018; 35(1):6-13.

[23] Carvajal MJ, Armayor GM, Deziel L. The gender earnings gap among pharmacists. Res Soc Admin Pharm. 2012; 8:285-297. [CrossRef] 
[24] Pardo K, Andia M, Rodriguez A, Pérez W, Moscoso B. Remuneraciones, beneficios e incentivos laborales percibidos por trabajadores del sector salud en el Perú: análisis comparativo entre el ministerio de salud y la seguridad social, 2009. Rev Peru Med Exp Salud Publica. 2011; 28(2): 342-351.

[25] Bertone MP, Witter S. The complex remuneration of human resources for health in low-income settings: policy implications and a research agenda for designing effective financial incentives. Hum Resour Health. $2015 ; 13: 62$. [CrossRef]

[26] Villar RA. Perfil farmacéutico de la República del Perú. OPS/OMS, Lima, 2012.

[27] Meyer CS, Mukerjee S. Investigating dual labor market theory for women. East Econ J. 2007; 33: 301-316. [CrossRef]

[28] Estadísticas de empleo. http://www2.trabajo.gob.pe/promocion-del-empleo-y-autoempleo/informacion-delmercado-de-trabajo/estadisticas-de-empleo/\#remuneracion (accessed August 1, 2018).

[29] Fischer LE, Chávez D. Percepción del rol que desempeñan las mujeres en puestos a nivel directivo del mercado laboral. Eur Sci J. 2015; 3:78-86.

[30] Patlán P. Efecto del burnout y la sobrecarga en la calidad de vida en el trabajo. Estudios Gerenciales. 2013; 29(129):445455. [CrossRef]

[31] Ansoleaga E, Vézina M, Montaño R. Síntomas depresivos y distrés laboral en trabajadores chilenos: condiciones diferenciales para hombres y mujeres. Cad Saúde Pública. 2014; 30(1):107-118. [CrossRef]

[32] Alcañiz M. Nuevas desigualdades en contextos de crisis: la precariedad laboral femenina en España. Proceedings of the First International Meeting of Industrial Sociology, Sociology of Organizations and Work. 2015; 507-526.

[33] Torres C. El trabajo doméstico y las amas de casa. Sociológica. 1989; 4(10):e1-e23.

[34] Galarza F, Yamada G. Discriminación laboral en Lima: el rol de la belleza, la raza y el sexo. Documento de discusión CIUP 185. Lima: Centro de Investigación de la Universidad del Pacífico. 2012.

[35] Informe Mundial sobre Salarios 2014/2015: Salarios y desigualdad de ingresos. http://www.ilo.org/wcmsp5/groups/public/---dgreports/---dcomm/--publ/documents/publication/wcms_343034.pdf (accessed August 1, 2018).

[36] Carvajal MJ, Armayor GM. Inequalities in the distribution of pharmacists' wage-and-salary earnings: Indicators and their development. Res Soc Admin Pharm. 2013; 9:930-948. [CrossRef]

[37] American Society of Health-System Pharmacists. Report of the ASHP Task force on pharmacy's changing demographics. Am J Health-System Pharm. 2007; 64:1311-1319. [CrossRef]

[38] Noonan MC, Corcoran ME, Courant PN. Pay diferences among the highly trained: cohort differences in the sex gap in lawyers' earnings. Soc Forces. 2005; 84:853-872. [CrossRef]

[39] Rizzo JA, Zeckhauser RJ. Pushing incomes to reference points: why do male doctors earn more? J Econ Behav Organ. 2007; 63:514-536. [CrossRef]

[40] Theodossiou I, Vasileiou E. Making the risk of job loss a way of life: does it affect job satisfaction? Res Econ. 2007; 61:71-83. [CrossRef]

[41] Rama C. Transformaciones en el mercado de trabajo de universitarios en América Latina: los impulsos al inicio de la fijación de salario mínimo profesional. Rev Diálogo Educ. 2015; 15(45):597-623.

[42] García C. Equidad e inclusividad en la educación superior en los países andinos. Revista de la Educación Superior. 2013; 42-2(166):137-144.

[43] Kogan L, Fuchs RM, Lay P. Sistemas abiertos y/o encubiertos de discriminación en el entorno laboral de pequeñas, medianas y grandes empresas en Lima Metropolitana (Documento de discusión). Lima: Centro de Investigación de la Universidad del Pacífico. 2011153.

[44] Kogan L, Kámiche J, Lay P.¿El origen socioeconómico y la raza pagan? Un estudio interdisciplinario sobre la discriminación racial y socioeconómica en el ámbito empresarial limeño. El caso de los egresados de la Universidad del Pacífico (Documento de discusión). Lima: Centro de Investigación de la Universidad del Pacífico. 2011.

[45] Conoce a las universidades privadas con las pensiones más caras. http://elcomercio.pe/economia/peru/conoceuniversidades-privadas-pensiones-mas-caras-noticia-1871520 (accessed August 1, 2018).

[46] ¿Sabes cuánto puede costarte estudiar la universidad en el Perú? http:// peru21.pe/actualidad/ sepa-cuanto-puedencostar-estudios-universitarios-2209916 (accessed August 1, 2018).

[47] Universidades del Perú. https://www.sunedu.gob.pe/lista-universidades/ (accessed August 1, 2018). 
[48] Goldin C, Lawrence FK. A most egalitarian profession: Pharmacy and the evolution of a family-friendly occupation. J Labor Econ. 2016; 34(3):705-746. [CrossRef]

[49] Botello HA, Guerrero I. Efectos de las características físicas en los ingresos laborales en Ecuador, 2012. Semestre Económico. 2017; 20(42):127-142. [CrossRef]

[50] Encinas V, Gómez MI, Contreras M. Dificultades de contratación en el mercado de trabajo para las personas con discapacidad: análisis desde la perspectiva de género. Revista Sociológica de Pensamiento Crítico. 2017; 11(2):71-81.

[51] Márquez-Scotti C. Determinantes del desempleo en las urbes mexicanas. Continuidades y rupturas en el período de crisis. Papeles de población. 2014; 83:101-134.

[52] Lohr S. Muestreo: diseño y análisis. México: Ediciones Paraninfo. 2000.

[53] Hosmer D, Lemeshow S. Applied logistic regression. Second edition. New York: John Wiley and Sons, Inc. 2000.

[54] INEI: Perú: Encuesta nacional a egresados universitarios y universidades. https://webinei.inei.gob.pe/anda_inei/index.php/catalog/329 (accessed August 1, 2018).

This is an open access article which is publicly available on our journal's website under Institutional Repository at http://dspace.marmara.edu.tr. 